地域産業保健センターに関して，平成 8 年度の認知度

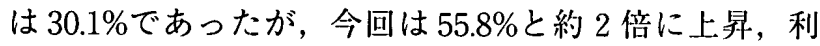
用度も $4.1 \%$ から $14.0 \%$ と上昇していた。この 5 年間に行 ってきた㕕報・㤵発活動や活動実績をより一層強化する ことにより，その認知度や利用率が着実に增加すること に碓信を得ることが出来た。

\section{8. 事例から見た職場における自殺予防対策}

○永田頌史, 三島徳雄, 久保田進也, 清水隆司，赤築綾子

(正業医科大·産業生態科学砳究所・精神保健学) 職場における自殺予防を目的として事例検討を行っ た. 対解者は有職者で, 自殺既遂者 18 例（男 17, 女 1 ）, 末遂者 4 例（男 2 ，女 2 ）である。職種は，専門技術者 8 例, 金融関係者 3 例, 現場作業者 3 名, システムエン ジニア 2 例，その他 6 例であった。診断名は，うつ病 12 例, 適芯障害 3 例, 精神分裂病 2 例, 重度ストレス 障害 2 例, その他 3 例であった。

職場での心理的負驸 (精神障羖等の学災認定基準参照) の内容は,「仕事の量・質の変化」10例,「役割・地位 の変化」5例，「仕事の失敗・過重な責任」 2 例,「その 他」5 例であった. 心理的負荷の強度はIII (強) が 6 例, II（中）が 12 例， I (弱) が 4 例であった。職場以外 の心理的負荷は 4 例, 個体側要因は 1 例にみられた。生 前に自殺のサインが認められた者は少数であった。

《結語》職場での自殺予防は, 日頃からの教育, ライン によるケア, 座業保健スタッフによるケアが大切である。

\section{9. コールセンターにおけるヘッドホン内騒音レベルに ついて}

○田代 拓, 藤代一也, 織田 進 （産業医科大・産業医実務研修センター）

【目的】某コールセンター作業者の騒音曝露を評価する ために,ヘッドホン内騒音レベルを調査した。

【方法】 3 人のヘッドホン内騒音レベル及び周波数レベ ルを調查した．測定はブリュエル\&ケア社のダミー人形 ヘッドトルソシュミレータ $4128 \mathrm{C}$ 型を使用し, 同社ポ ータブル PULSE3560 C型で分析した.

【結果と考察】 $\mathrm{A}$ 氏の騒音レベルは平均值 $78.7 \mathrm{~dB}$ (A) \pm 4.11 周波数約 $200 \sim 4,000 \mathrm{~Hz}, \mathrm{~B}$ 氏は平均值 $79.5 \mathrm{~dB}$ (A) \pm 4.88 周波数約 $200 \sim 5,000 \mathrm{~Hz}, \mathrm{C}$ 氏は平 均值 74. $4 \mathrm{~dB}$ (A) \pm 5.75 周波数約 $200 \sim 4.000 \mathrm{~Hz}$ で あった。職場内環境騒音レベルは, 平均値 $57.7 \mathrm{~dB}$ (A) \pm 0.93 周波数約 $63 \sim 8,000 \mathrm{~Hz}$ であった.

ヘッドホン内虽音レベル及び職場内環境騒音レベルは 第一管理区分に相当する．更にヘッドホンは片耳ヘッド ホンであり，耳の変更により片耳への負担は，労働時間 の $1 / 2$ まで削減できる。

\section{0. 沖縄県における草刈機使用者の聴力, 振動覚閾値 及び運動機能検查の検討}

○山本宏実 ${ }^{1}$, 鄭 茎城 $^{1}$, 有泉 誠 $^{1}$, 高橋幸雄 ${ }^{2}$, 前田節雄 ${ }^{2}$

( ${ }^{1}$ 琉球大·医・保健医学, ${ }^{2}$ 産業医学総合研究所) 沖縄県に扔ける草刈業務は, 過酷な炎天下で行われる ことが多く，従事者も高歯であることから他府県とは異 なる健康問題を有することが推測される，本調查は沖綶 県にお污草刈機作業従事者の感覚，連動系に関する検 查成績を検討し，特有の身体状況を把握することを目的 とした。

対象は沖縄県で草刚機を用いる作業に従事する者 4 名 と対照者 13 名で, 聴力, 振動覚閾值, タッピングなど を測定し, 比較した。

聴力は典型的な $\mathrm{C}_{5} \mathrm{dip}$ パターンを示すものがあった．振 動覚閾值，つまみ力は有意な差は無かったが，右第 2 指 のタッピングは沖䋲県の作業者で有意に回数が多かっ た．本土と異なる作業環境が何らかの影響を及ほしてい る可能性もあると考えられる。

\section{1. 産業医科大学における産業保健実務相談密口の現} 状

○井手 宏, 吉川里江, 内田和彦, 藤代一也, 織田 進,

東 敏昭（産業医科大・産業医実務研修センター）

産業医科大学・産業医実務研修センターで行っている 産業保健実務相談空口（以下相談空口）の相談内容 （1992-2001 年）および相談窓口を利用して当大学内で 産業医修練を行うシステムについて吿告を行った。

相談空口に笴せられた 451 件の相談を分野ごとに分類 したところ物質の毒性や生体影斯に関連する相談が $43 \%$ を占め, 適正配置を始めとする労務管理や種々の検診を 実施する上での法令解䣋および運用の具体策についての 相談も多く (39\%), 個人で広い分野に対応する産業医 業務をサポートするシステムの必要性が明らかとなっ た.

また，産業医科大学における産業医学卒後修練期間中 の医師（産業医学專門修練医）が上記相談に対する回答 者を担当することによって，単に相談事䐜に関する知識 だけでなく, 種々の現場で起きている問題点に触れ, 回 答作成の過程で資料収集や問題解決の方法などを習得す る利点があると思われた。

\section{2. 医療費の自己負担增による高血圧症患者と糖尿病 患者の受診行動への影響}

○馬場園 明 ${ }^{1}$, 宮崎元伸 ${ }^{2}$, 撂 博 $^{2}$

( ${ }^{1}$ 九州大 · 健康科学センター, ${ }^{2}$ 福岡大・医・衛生) 【目的】わが国の被用者健康保険の自己負担率が，1997 年 9 月より 1 割から 2 割に引き上げられた。この自己負 